\title{
Women Veiling In Islam: Tradition And Socio-Economic Impact
}

\author{
Nasreen Aslam Shah \\ Women's Studies \& Social Work \\ University of Karachi
}

\begin{abstract}
The Veil has been used by women as a tool for hiding and protecting themselves from men, and it has been continuously used in ancient as well as modern civilizations by women. Developed nations have blamed the use of veil as an obstacle in the process of development. Therefore, modern nations have tried to get rid of the use of veil. They argue that it is a sign of slavery for women and it is a hurdle in their progress. The modern secular Muslims consider it as the biggest obstacle for social and economic development. It makes a woman helpless, as having a chain (zanjir) in her feet. Some people view it as a tool of segregation between men and women. In the Holy Quran word 'Hijab' is used 7 times. Islam is against domination and the forceful practice of the veil, as a part of the teaching of Islam it is being adopted by women for the purpose of protection. This article focuses at: Introduction of the veil and its historical background, It's meaning and interpretation in Islam and other religions, Veil traditions in different civilizations, criticism of its practice in Islamic (eastern) and other (European) circles and Discussion and Conclusions followed by a selected references.
\end{abstract}

Keywords: Veil, Tradition, Islam, Socio-Economic Development, Social Change.

$$
\begin{aligned}
& \text { تلخيص }
\end{aligned}
$$

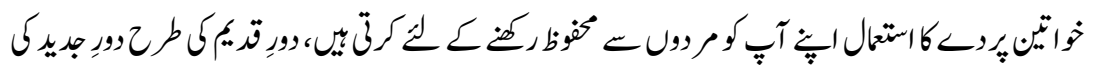

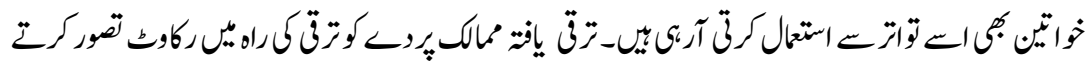

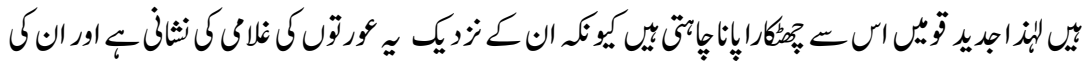

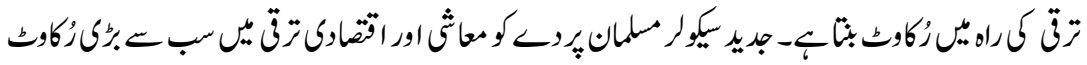

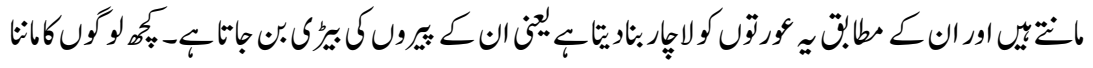

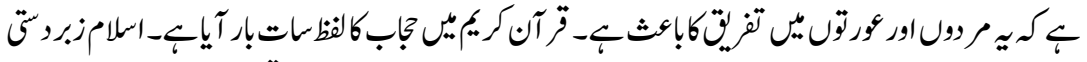

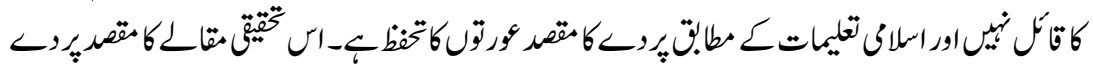

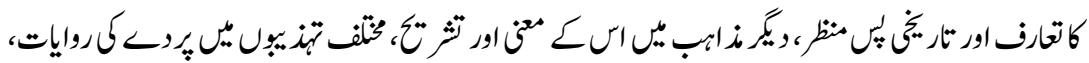

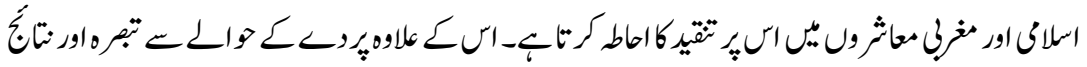

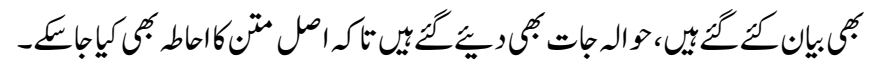

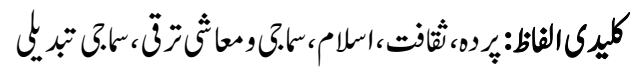




\section{Introduction}

The word "Purdah" or "Pardah" has been derived from Persian language means "Curtain". In some Muslim as well as in Hindu communities such as Rajputs, upper class of Hindus in the Northern India, veiling is commonly practiced to maintain women's privacy religiously and socially. Purdah or veil can be categorized into two forms, one with the idea of segregating men and women, secondly the requirement of women to cover their body for their protection in public spheres. Whereas, the sensible use of curtains, screens and walls is a way of segregation within the buildings (US Library). Women are usually restricted in their personal, social and economic activities outside the home due to purdah. Usually a gown type dress or garment is worn and is called burqa, few women use yashmak to cover face also. Sometimes even eyes are covered by yashmak and only close male family members can see them. But in some societies purdah is observed only on special occasions of religious importance. In Northern India, married Hindu women observe "ghoonghat" before elderly male relations from husband's side, in order to show respect towards them, but this custom is not popular in other parts of India. In different languages terminologies for veil with different spellings are used, for instance 'purdah' in Persian and Urdu, 'Hijab' in Arabic, ${ }^{1}$ and 'pardah' in Hindi (Brintanica.com 2000). ${ }^{2}$ We may elaborate its literal meaning by different words like layers, mask, privacy, protection, safety, sense of secrecy and modesty (Donzel, 1978). The concept of veil began with the emerging sense of morality in humans. Basically, women use the veil to hide themselves from men and it has been a continuous practice of women in early and contemporary civilizations.

According to many historians purdah was originally adopted by Persian Muslims in the 7 th century C.E. during the Arab conquest of Iraq. Later the veiling practice of Hinduism was influenced to the upper classes of Hindus in northern India, and was also spread by the Mughal Empire. Especially in the British colonial era in the sub-continent purdah was observed more strictly by the Muslims (Btritanica.com). Though purdah is generally linked to Islam, but many scholars have proved with their arguments that it is a pre-Islamic concept of segregating women. Veiling is commonly practiced in many Middle Eastern groups like Druze, Christians and Jewish (Asha, 2008). Even before Islam the upper class women's mobility of Babylonian, Persian and Byzantine Empires was restricted (Ahmed, 1990). History has evidences of veiling before Islam and dates back to 7th C.E., therefore, Islam just added a religious and spiritual importance to preexisting practices (Britanica.com). In northern Nigeria the veiling concept is rather new i.e. after the uprising of Boko Haram (Harnischfeger, 2014). Veiling has many reasons other than religion to be practiced in the upper classes in India and commonly in Pakistan (Britanica.com). Initially the concept of pardah was adopted to protect women from harassment, but later it became the way of 
marginalizing the mobility of women to take full control of their lives (Asha, 2008; Naim, 2004).

Few other scholars state that it was always observed as local custom and was later adopted religiously to have control of women's actions, doings and behaviours (Shaheed, 1886). By viewing the historical pictures of Rajput royal families of Barodha state, it was observed that women used to travel in a silver 'zenana' baghi (silver horse carriage specific for women) which clearly demonstrates that pardah was observed by their women in public spheres (British Library, 1895). Pardah is considered as pride and chastity symbol, and a way to judge women's inner beauty i.e. judging her purity on the basis of pardah (Arnett, 2001; Papanek, 1973). Especially among Rajputs veiling is considered as a sign of dignity and modesty therefore, women had to follow it strictly (Ansari, 2010).

Developed nations consider the use of veil as an obstacle in the process of development. Therefore, modern nations have struggled to get rid of veil. They argue that it is a sign of slavery for women and it is a hurdle in the path of development. It makes a woman helpless, as being Chains (zanjir) in her feet. It is also considered as a tool for segregation between men and women ${ }^{3}$ (Haque, 2008; 63). The so called Muslims of the modern era are trying to adopt western trends by imitating the modern nations of the world. These acts of the Muslims have been explained by Allama Iqbal the poet of the East. According to Allama Iqbal, Muslims have interpreted religion wrongly in order to become modern. The modern secular Muslims consider veil as the biggest obstacle regarding social and economic development, whereas, for adult Muslim women it is mentioned in the Holy Quran, to cover their body. In particular ways for Muslim women, use of veil in Islam is must. It is a right provided to a woman by religion and it provides her strength as well.

In the Holy Quran word 'Hijab' is used 7 times. Islam is against domination and the forceful practice of the veil. As part of the teachings of Islam, it is being adopted by women for the purpose of protection. It protects and prevents from any quarrel. Since centuries, the word veil has been used and discussed in eastern and western civilizations.

\section{Meaning and Interpretation in Islamic and other Religions}

\section{Veil in Christianity}

According to Christian scholars, Ziauddin (2004:45) women are a doorway for the entrance of the devil, this concept is linked with Adam and Eve regarding forbidden tree and in Christianity Eve is blamed for leading Adam to that forbidden tree by breaking the God's limitations set for them. In Christianity 
virginity is considered a high level of virtue for a woman (Sheikh, 1987:85). Therefore, women prefer to be virgin and after marriage, there is no concept of divorce in Christianity. In extreme situations, separation of husband and wife is allowed, but women cannot remarry, and it promotes illicit relationships between men and women. But it is declared that in civilized nations and Christianity there are equal rights of men and women now and she is not considered as lower. Women have got equal rights and due status in Christianity. Though socioculturally there are still some restrictions for women and even today they are considered as slaves of husbands (men).

\section{Veil and Islam}

For Muslims Islam is not just a religion, but a perfect way of life for them. Islam has instructions for women to protect themselves and to cover their body properly in a manner that no one can get attracted by their beauty and sexual appeal, they may wear a veil and Hijab (it is not an Islamic code but women can adopt as per the set standards). The veil is a sign and symbol of Muslim character. It protects from social conflicts and creates social rules and regulates stages of life and harmony among them. On the other hand, helps in performing socio-cultural, political, economic and sexual relations and is like a pillar in the sexual development. Evolution of human lives and human civilization depends on inner and outer implementation of veil among human beings. It protects both men and women from rapes' and sexual exploitation, from being victims of unethical practices of lust, sex and altruism and helps to get sexual perfection and satisfaction.

The Quran has clearly set the standards of moral ethics for men and women both. Modesty is the key ingredient of all aspects of man's life, i.e. their actions, morality and even way of speech. Islam has given clear instructions regarding their behaviour, and dress code to avoid needless display of their bodies to seek people's attention, i.e. they must adopt modest dressing. Men have special commandments in Islam to lower their eyes and not to brazenly stare at women.

The prophet Muhammad (PBUH) said that, "Tell the Momin men to keep their eyes lower to protect their dignity and respect; it is a way for their purity." The prophet Muhammad (PBUH) said the same for the women. "Tell the Momin women to keep their eyes lower to protect their dignity and respect; it is a way for their purity." Button up their veil in front of their breasts and keep it secret from men. Tell these women to keep themselves away and protect themselves and their secret body parts from servant men in the home who have nothing to do with the employer women. Women must also keep them away and in veil from boys who are yet not aware of the women secret matters. In Surah Nur of the Sacred Qur'an it says, men should lower their eyes and secure their modesty; that will make 
them pious and pure, and Allah knows what they do, as Allah is all knowing. There are misconceptions regarding Muslim women's veil due to deviation from true Islamic doctrine. The veil concept arises from Arab and Muslim countries, and is questionable as Islamic ideas are now mixed up with polytheistic religious customs.

In Islam, women as well as men have been advised to hide their sexual organs under the veil. All the time at any place they are instructed to keep them under a veil, not supposed to disclose or unclothe their private body parts that promote, instigation or stimulate lust for sex in others persons mind, male or females. Though in special cases, men and women are allowed to expose their body to doctors for treatment or judges in case of any legal requirement. Under this rule men from men and women from women must also keep their sexual body parts hidden. Sex organ of men included from belly button 'naf' till knees (half of the lower body till his knees). In 'Surah Nur, there is a complete instructions about keeping the sex organs hidden. The veiling of sex organs is for unmarried men also.

\section{Islamic Perspective and Islamic Teachings about Veil}

According to Islamic teachings, women are instructed to cover their body properly and should not mix up with men. A veiled woman is forbidden for men like a forbidden tree. Islam allows women to come outside the home, but her whole body should be fully covered in an appropriate dress so that men do not get attracted by their beauty. These obligations are imposed for increasing the respect and dignity of women. Man and woman must come out of their homes in such a manner that their honour, respect, dignity, polity and purity clearly demonstrate their pious status. There are complete instructions given in the Holy Quran in Sura-e Ahzab: "Oh you, who believe, do not enter the house of the Prophet unless you are given permission (Maudodi, 1999:279). Prophet Muhammad (PBUH) said that, "Allah has permitted you to come out of your homes to fulfill your needs" (Maudodi, 1999:280). After the revelation of the verse of Hijab, Hazrat Aisha used to put on the veil, whenever, she goes out of her home.

Once at the time of Hajj, when women asked Hazrat Aisha to come along with them to kiss Hijr-e-Aswad to exhibit love and reverence. Hazrat Aisha told them that they can go without her because she was not allowed to go into the crowd of men. During the day time when she wanted to have Tawaf-e-Kaba the men were being sent out of Khana -e-Kaba and Hazrat Aisha covered her face fully before going for Tawaf. 


\section{Historical Background and Its Existence in Civilizations}

\section{Existence and Emergence in Greek Civilization}

Historically veil among women started in 13 century BCE and it emerged from the Assyrian kingdom (Greaber, 2011). At the time of its peak Greeks were considered one of the greatest kingdoms of the world. It seems that the status of women was low from the beginning (Maudodi, 1999:14). Veiling among noble and rich women was seen as a status symbol. They had separate rooms for women and men inside their homes. There were no common gatherings, meetings and celebrations in Greek civilization and women used to observe veil (Maudodi, 1999:15). After marriage, men and women used to live their life gracefully. It was the peak time of the Greek civilization. Although, veil was being practiced by women, but men had no special restrictions, and they used to enjoy more powers than women. Even men used to enjoy relations with the widows because it was not considered a social evil.

\section{Roman Civilization}

The Roman Civilization was considered as one of the greatest civilizations of its time. To corroborate that the veil was the standard mode of dress that symbolized virtue or chastity for roman matrons according to Hughes (2007) during the Augustan period (27 BCE-CE-14). In roman civilizations relations of men and women were considered valid only after marriage. Veiling was not practiced during the democratic period of Roman Civilizations but women were watched and guarded very closely. The dignity and sexuality of women was considered a high level of character at that time. When new ideas and novelty came in the civilization, later with time widows were also given high ranks and status.

\section{Indian Civilization}

Indian old Hindu civilization is considered one of the oldest civilizations of the world. Status of women in Hinduism is one of the lowest as compared to other civilizations. Socio-Culturally, there is no binding on Hindu women for wearing the veil in the Hindu civilization (Parkas, 1912:378-379). In Hinduism it is believed that nothing is more dangerous, bad and poisons than women not even a fate, snake venom, death and hell etc. According to Rig Veda in Hindu religion, it is mentioned that God made you a woman, so you shall lower your gaze and do not look at men. Keep your feet close, cover your hair and should your body fully with the veil. And for men Rig Veda says "It is not good, that man covering his thighs with female garment". When Ram saw the Paruslio Ram coming, he told seta to keep yourself in the veil and lowers your gaze. 
In Hinduism woman were considered as a commodity and has very low status, they were sold and purchased, especially the women of lower caste because of very lowest status, being powerless and were treated as slaves (Parkash, 1912:378-379). There are only duties and no rights in Hinduism for women. In all sphere of life, she is entirely at the mercy of men; therefore, women rights in Hinduism or Indian civilization are never considered important.

\section{Women in Arab}

In ancient Arab women did not use to veil. Men and women used to attend all celebrations together. But then the Muslims of Arab started adopting segregation of men and women among the Arabian culture and promoted the use of veil among women. It also promoted the system of separate rooms for women in the homes.

\section{Women Veiling in Eastern (Islamic) and Western (European) Circles}

Among the civilized societies there are two motives or notions of sexual relations. First, is to have an offspring, become a father or parents, and have children. The Second is based on love for chastity, but being contaminated with sexual lust and can be called a faith in living a life as an unmarried, a celibate, bachelor in case of man and or virgin in case of a woman. According to Bertrand Russell the sexual relations and mankind existed are based on the first motive. But in India and Persia the second motive prevails, because there is veil existing between men and women and sexual relationships have abstinence (Papanek, 1973; Russell, 2000:138).

\section{Women Veiling in the Modern Age}

France, German and Holland are highly developed and industrialized nations of the western world and they attained the economic development but they completely banned women veiling in their countries. In France, in 1994 head scarf for female students was completely banned. On November $2^{\text {nd }}, 2003$ a bill for banning the women veiling was submitted in the parliament and was approved by majority. At this point we can mention a statement of Jacques Chirac, the French president mentioned (December 17, 2003) "it is my view that wearing symbolic items having religious significance like wearing head scarf and cross etc., which conspicuously demonstrate religious affiliations, must be banned in state schools (Chaudhry, 2005). In the $19^{\text {th }}$ century mix gatherings and assaulting women sexually was not considered as sin. According to a journalist, Paul Bureau later in French towns and cities young boys and men started realizing that when they themselves are not pure and virgin, they have no right to demand from women/girls to be pure and virgin. In towns like Burgan Bon and many other 
surroundings' woman, before marriage use to enjoy friendship with many boys/men (Al Jazerra 2008; BBC, 2006).

According to Guindi (1999) the discussion on veil has a principal impact of western feminist ideology, who consider it as a women's sub-ordination and oppression. In fact the main reason for practicing veil is to avoid evil and harmful incidents (Fitna). According to President Shirac veil shows a sign of resistance. Whereas, according to an Arabian, Dutch journalist the naked culture of France is in danger from the women veiling (Sciolono, 2003). In Afghanistan, Saudi Arabia, Iran, state of Zamgara of Nigeria and Kelantan province of Malaysia there is a law on wearing a veil. In England women veiling has no restrictions. In USA women rights organizations consider veiling of women as a reaction of men's torture and exploitation of women.

\section{Women Veiling a Social Problem of the Modern Age}

When Western nations discussed veil as a biggest obstacle in the progress of Muslims, they tried to develop realization in Muslims, that it was a real cause of their backwardness. Although there is a clear instruction about the veil in the holy Quran, in Europe discussions and conferences started to get the opinion for abandoning the use of veil among the Muslim families. Muslims families, in western nations started allowing their women to follow the culture of the west to become one of them. Muslims started thinking and discussing about purdah and its impact on their existence. In Islam, Muslim women and men are equal in performing their due roles that separates them from each other (Magahi, 1996; Michael, 2003).

\section{Anti Veiling Movement in Europe}

An anti veil movement started from France in 1989 from one school when three girls were ousted from school for wearing scarf. From that day, time to time girls from schools and women from offices and other places of employment were ousted. In 1990 in the baling village of Southern France, a Muslim girl student was ousted from school on account of wearing a scarf. Muslims parents complained about the action, but a principal started a movement against the scarf. In 1994 wearing of head scarf was completely banned in public schools and government institutions through a memorandum. In 2003 an act of parliament was approved, and in 2004 a complete ban was approved by the French Parliament as a law and was implemented by the government, thus banning scarf completely. Turkey even a Muslim country in 2009, introduced a complete ban on scarf. Although $65 \%$ women wear scarf, but from the time of Kamal Ata Turk, there is a ban on scarf. In Turkey secular elements are against women wearing 
head scarf while many women favour it. In Turkey veiling of women is disliked by the government as well.

In England there is no ban on the veiling of women. In 2004, in London a meeting was called by Mr. Livingstone the mayor of London. 300 delegates were invited while Allama Yusuf Al Qazvin presided over the session. In this session the house demanded from France to remove a ban on veiling (Jung, 2009). Because it encouraged the fencing attitude of the Jews regarding veil. Mayor of London Mr. Livingstone informed the Muslims that they will not be treated like France and Germany in London that the ban on veil will not be imposed, but in-spite of that still this religious Muslim custom is being criticized in England (Abdelhadi, 2006).

In Italy, covering face with a veil is prohibited, and they considered veiling of women in the same context and therefore, veil is banned in Italy. In Holland, there are $5 \%$ Muslims, but by the order of the president of the immigration at the public places veiling of the face is unlawful. According to Scott Campbell "Holland has banned the full-face Islamic veil in government buildings, schools, hospitals and on public transport after a fierce debate on the burqa" (Campbell, 2015). According to Barak Hussein Obama USA president, Muslim women must get this right to wear a scarf on their head and practice their religious rules and laws and fulfill their obligations (Book Worm, 2009; Facing History and Ourselves Foundation, 2008)

According to Maulana Muhammad Saeed Al Tantavi head of the Jama-e-Al Azhar of Egypt, "it is the internal matter of France to make laws on banning of Veil and scarf. He asked the Muslim women living in France to avoid wearing of veil and head scarf to follow the country rules and avoid any further conflict and controversy (BBC, 2006). On the other hand other Egyptian Muslim scholars consider the veiling of women as a binding duty of women as an order from Allah (Marco, 2014). Among the European women, without the regard of religious boundaries and teaching veiling of women and wearing of head scarf is becoming popular as a fashion and modernism (Hussein, 2012).

Tunisian and Turkish governments have banned the use of veil in the academic institutes and government offices, to discourage the demonstration of Islamic fundamentalism. Due to resentment on the national and international level, the Higher Education in Turkey has issued orders to colleges and universities not for taking any actions against those students and women who are wearing head veiling and a scarf whereas, private institutions are taking no actions against the students who wear veil and scarf (Al Jazerra English, 2008). 


\section{Discussion}

According to Islamic guidelines, women are allowed to go out and perform their work, but within limits (Shariah) and in appropriate dress. Social evils have damaged cultural and family ties and thus social values are deteriorating. In the contemporary world western powers are targeting Muslim nations and Islamic ideology. They criticize Islamic law and religious practices like veiling, Jihad (Holy war), Honor of the Prophet (PBUH) and family systems are their special targets. Everywhere, these practices are being connected to the phonetics, extremisms', terrorism and Islamic fundamentalism (Jung, 2009).

In European countries laws are being made against veiling as it is a symbol of Islamic custom and religious practice, but it has created many controversies. In France since 2004, all religious symbols, including Muslim headscarf are banned. In South Asian countries like Pakistan, Bangladesh and India pardah is considered as a sacred religious practice, therefore, there are no policies against it. Since Pakistan has many conservative laws and policies which use Islamic expression (Islamic Shariah), can also be termed as Islamization, therefore, people here observe Islamic Shariah and Islamic laws freely. A nation can never be liberated unless a woman is liberated so there cannot be a true freedom if a woman is enslaved (Singh, 2005:1-8, 23-25). The Islamic ideology liberates and strengthens the conventional lifestyle, women's reproductive role and women's honor and dignity. But it is our society and discriminatory laws that marginalize women in both private and public life and thus, widening the gender gap by promoting gender segregation. Women are facing the challenges that arise from pardah and giving rise to gender inequality. Laws and policies in Pakistan have liberated women to a certain extent in trade unions, right to vote, decision making and seeking opportunities, but this liberation has labeled them as being westernized and going away from their traditional roots.

Factors that have affected Pakistani women's pardah observance may include globalized trends and the return of Pakistani women from abroad with new ideas and life styles (Haque, 2010). One significant aspect of these trends is less observance of purdah i.e. strict pardah covering face is considered as being conservative. Pakistani people who live abroad have less restricted attitude towards pardah, because it hinders them in getting involved in educational and economic activities. Parents of immigrant families do not force their daughters to observe pardah, but if they do then it is totally their own wish to follow Islamic roots and culture. Scholars have their own perceptions regarding veiling of women; few consider that the main aim of pardah was to protect women from being sexualized (Asha, 2008: 41-51). But in the contemporary world, our society still sees pardah as women's safety when they move in public spheres and it is a symbol of honour and pride (Haque 2010: 303-310). However, this view faces 
criticism that rather than preventing women from sexual assault by perpetrators, focusing on women veiling to remain protected in not justified. Pardah is considered and criticized as one of the main reasons of women's oppression, and they are marginalized from accessing resources like education, career opportunities, political empowerment and freedom of driving their life according to their wish.

P. Singh and Roy have interpreted pardah as the source of male supremacy in society and a dark shadow on Muslim women's distinctiveness and individualism (Singh, 2004). When pardah was established as a part of local laws and a dress code of Muslim women, the institutionalization of pardah marginalized women's mobility, their empowerment and freedom in both public and private spheres. This stereotypical mentality of society is due to the policies which promote the social and cultural norms resulting in less mobility of women in public space, increased gender segregation and gender differences.

\section{Women Veiling (Purdah) as a Symbol of Women Empowerment}

The resurgence of purdah is sometimes considered as an argument for better and improved gender relations. Women usually use the veil and the head covers for improved and uninterrupted mobility. Besides the false perception of western countries, Muslim women considers pardah as a tool of their empowerment and an easy way to achieve access to rights in public and private space regarding education and economic independence. For example, rural women in Bangladesh, who observe burqa are more vibrant and have a higher social contribution, thus have increased women's status (Feldman and McCarthy, 1983).

The developed nations and civilizations who have ruled over the entire world were also sociologically and ethically highly civilized (Singh, 2004). Islam is a religion that does not allow men and women to live their life as a monk/nun, it rather encourages living a happy and successful life. It allows men and women to benefit from the bounties of the world. In Islam the physical appearance of a woman and men should not be objectionable (Hossain, 2001; Nelson, 2013; Jehan, 2003). Islam allows women to perform daily duties and they are encouraged and allowed to come out of their homes to perform their duties. She is allowed to get education and can work in organizations and institutions to earn and satisfy and fulfill her needs of daily life. She has the right to fulfill her sociocultural and economic needs and requirement. Allah has given a right of freedom in all spheres of life. But this freedom has some responsibilities and it is based on certain conditions. These conditions are based on the natural responsibilities and situation. The Islamic teaching encourages woman to perform all of her life affairs, but in the light of the teaching of Islam and ethical boundaries like her body must be covered properly, especially when going out of her home (Al 
Quran, Surah Nur: verse 30). In Sura-e-Al Ahzab (Al Ahzab:59) Allah says, O prophet tell your wives and daughters and Muslim women to cover themselves with their Chadirs (shawls), it is good not to be recognized by others, so that none can abuse them and Allah is forgiving and merciful.

Before the advent of Islam, women used to go out unveiled to attract men, these women were teased by some men. Taking into consideration such situation was not acceptable: therefore, Allah advised and forbid women that they must cover their body and sexual parts to be respected by others when they move in public. After the revelation of the verses regarding veil of women, women of the family of the Holy Prophet (PBUH) used to cover their body in public places, even at the time of Hajj and Tawaf-e-Kaba they veiled themselves. They were allowed to unveil their face and hands at the time of Hajj, so that others can recognize them and respect them instead of being teased.

\section{Conclusions}

There are four Imams in Islam, according to them:

- Imam Abu Hanifa: a stranger is not allowed to stare at other woman, but he can see her face.

- Imam Shafi: all parts except the face and hands of a woman should be veiled.

- Imam Humbal: except women face all body should be veiled.

- Imam Malik: all parts of women's body should be veiled except her both hands and face (Sheikh, 1987:127).

In the light of teaching of Islam, there are two schools of Muslim (thought) scholars.

One is in favor of complete veiling of women and another is not. Those who favor veil are providing references of the Holly Quran and Hadiths in favour of their opinion that all parts of her body must be fully covered.

Second group comprising on those who are in favour of women's veil, but they agreed that woman can take her face and hands out of the veil to perform her daily activities and essential work of her life. Because several socio-economic and religious duties and functions cannot be performed in veil so they are bound to unveil their face and both hands. In case if all parts of a woman's body are fully covered she must be in a big trouble fulfilling her daily duties. Therefore, they can unveil their face and hands for doing work, but while unveiling them (face and hands) Allah has ordered that woman should lower their eyes. 
In a particular situation woman has to decide when she has to put a veil under what conditions. In teachings of Islam, there are no clear instructions for the veiling of hands and face (Maudodi, 1999:266). Allama Iqbal the poet of the east has also advised women to follow the Islamic teachings in daily life. A mature pious (Momina) Muslim woman is fully respected having trust on Allah and confidence on herself. She must make her own decisions and Judgments to follow instructions (Singh, 2005:8). To create peace in society women are bound to make up themselves. She can decide when to unveil herself to perform her duties and daily routine matters of life (Soharwardi, 2001:293).

\section{End Notes}

1. Hidjab is commonly spelled as hijab and higab as well.

2. Three languages of the Eastern civilizations, Farsi (Persian), Urdu, and Hindi are languages of the Indian Subcontinent. Farsi disappeared from the subcontinent with the fall, of Mughal but it is still spoken in Iran and Afghanistan. The Urdu is a national language of Pakistan and Hindi is spoken by Hindus of India.

3. The need to control women originates from the issue of inheritance through the male line. Thus female virginity and fidelity became of central concern, and women's contacts with males were restricted to determine the fatherhood of children.

4. Book Worm. (2009). Obama again celebrates putting women in hijab and niqabs (I'm noticing an interesting pattern in Obama's Muslims speeches. He thinks it's a very good thing for women to cover up. In his Cairo speech, he made that point, not once, not twice, but three times. http://www.bookwormroom.com/2009/09/01/obama-again-celebrates-puttingwomen-in-hijabs-and-niqabs/ (September 1, 2009, bookworm, accessed on September, 2015).

5. Harnischfeger, Johannes. (2014). Boko Haram and its Muslim critics: Observations from Yobe State. In Pérouse de Montclos, Marc-Antoine. Boko Haram: Islamism, politics, security and the state in Nigeria (PDF). Leiden, Netherlands: African Studies Centre (ASC). p. 41. ISBN 978-90-5448-135-5. Retrieved August, 2015. Both rich and poor presented themselves as pious Muslims but took a very limited, selfish interest in the law of God. Most kept their wives in purdah but had little compunction committing adultery with unmarried girls.

\section{References}

Abdelhadi, M. (2006). Tunisia Attacked Over Headscarves, BBC News, September 26, 2006. (Accessed September, 2015).

Abid, S. (2011). Purdah, The All Concealing Dress, Vienna University, Social Anthropology, vol.7:9. 
Ahmed, L. (1989-90). Women and the Advent of Islam: Women Living under Muslim Laws, vol.7:8, pp. 5-15.

Al Jazerra English. (2008). Turkey Head Scarf Ruling Condemned (07 June 2008), (Accessed on September 2015).

Al Quran: Surah Al-Ahzab: 59

Al Quran: Surah Al-Ambiya: 23.

Al Quran: Surah Nur':30

Ansari, N. (2010). History of the Later Harappans and Silpakara Movement (2 Vols.), p. 159.

Arnett, S. (2001). Purdah, London: King's College History Department. Journal of History. http:// departments.kings.edu/ women's. History/purdah.html (Accessed August 2015).

Asha, S. (2008). Narrative Discourses on Purdah in the Subcontinent, Journal of English Studies, vol.3:2, pp. 41-51.

BBC News. (2006). French MPs back headscarf ban, BBC news, Britanica.com. Encyclopedia (http://www.britanica.com/2000 (Accessed September, 2015).).

Britannica Online Encyclopedia. (Accessed August 17, 2015, http://www.britannica.com/EBchecked/topic/483829/purdah)

Britannica.com, Encyclopedia. Rajput, (Retrieved August, 2015).

British Library. (1895). Princely States of India Oriental and India Office Collection, London: British Library.

Campbell, S. (2015). Holland has Banned the Full-Face Islamic Veil in Government Buildings, Schools, Hospitals and on Public Transport after a Fierce Debate on the Burqa, Scott Campbell, (Saturday May 23, 2015 at 10.22).

Chaudhry, A. S. (2005). Middle Eastern and Asian Languages and Culture, "The Simulacra of Morality": Islamic veiling, Religious Politics and the limits of Liberalism, Springer, Dialectical Anthropology, vol.29, pp.349-372. New York: Colombia University. 
Dozel, E. Van. (ed). (1978). Encyclopedia of Islam, vol.5. Leiden: Koninklijke, Brills. E. J. Brill.

Facing History \& Ourselves. (2008). Stories of Identity: Religion, Migration, and Belonging in a Changing World. Brookline, MA, USA: Facing History and Ourselves Foundation, Inc. p. 101. ISBN 978-0-9798440-3-4.

Feldman, Shelley \& Florence McCarthy. (1983). Purdah and Changing Patterns of Social Control among Rural Women in Bangladesh. Journal of Marriage and Family, vol.45:4 pp.949-959. http://www.jstor.org/stable/351808. (Accessed November 24, 2015).

Greaber, D. (2011). Debt: The First 500 Years, Brooklyn, New York: Melville. House.

Guindi, E. F. (1999). Veil: Modesty, Privacy a Resistance. New York: Columbia University Press.

Haque, R. (2008). The Institution of Purdah: A Feminist Perspective, Pakistan Journal of gender Studies. Karachi: vol.1, p.63.

Haque, R. (2010). Gender and Nexus of Purdah Culture in Public Policy, South Asian Studies, vol.25:2, pp.303-310.

Harnischfeger, Johannes (2014). Boko Haram and its Muslim critics: Observations from Yobe State, In Pérouse de Montclos, Marc-Antoine.

Hossain, M. K. \& Kabir, M. (2001). Purdah, Mobility and Women's Empowerment and Reproductive Behavior in Rural Bangladesh, Social Change, vol.31:3.

http://ur.imam-khomeini.ir/en/key/Islam/page10, (accessed September, 2015).

http:www.onlyislam.net, (accessed on January 30, 2015).

Hughes, Lisa A. (2007). Unveiling the Veil: Cultic, S, and Ethnic Representations of Early Imperial Freedwomen, The Journal of Objects, Arts and Belief, vol.3:2, pp.218-241.

Hussein, I. (2012). Women Veiling, Karachi: The Daily Dawn, (Tuesday, October, 1, 2009, Dawn Press). 
Jehan, M. (2003). An Analytical Study of the Status of Women before Islam, Karachi: Pakistan Journal of the Gender Studies.

Jung. (2009). Women Veiling, Karachi: Jung Press, (Friday September 4, 2009).

Khazan, O. (2013). Face Veils and the Saudian Plague, The Atlantic: The Atlantic Media Company. (Accessed August, 2015).

Khomeini. (2000). Woman in the light of Khomeini's Teaching, Lahore: Islamic Publications Ltd.

Magahi, M. S. (1996). Woman in the Veil, Karachi: Dar-ul- Sakaftaia Is lamia.

Marco, O. (2014). The Hijabization Process: Some "Mindful" Bodies Uncovered (PDF). Iemed.org, (accessed July, 2015).

Maudodi, Syed Abu-al-Ali (1999). Veil, Lahore: Islamic Publications Ltd.

Michael, A. et al. (2003). Women's Status and Domestic Violence in Rural Bangladesh: Individual- and Community-level Effects, Demography, vol. 40:2, pp.269-288.

Nadvi, S. S. (2012). Characteristics of Hazrat Aisha. Lahore: Islamic Publications.

Naim, C.M. (2004). The Hijab and I, Outlook Magazine (http://www.columbia.edu).

Nelson, D. (2013). Kashmir Women Ordered to Cover Up or Risk Acid Attack, The Telegraph, sec. World, August 13, 2012. http://www. Telegraph. co. uk /news /world news/asia/india, (Accessed August, 2015).

Papanek, H. (1973). Purdah: Separate Worlds and Symbolic Shelter, Comparative Studies in Society and History, vol.15:3, pp.289-325.

Parkash, S. S. (1912). The Begging of Indian Myth from in "The Story of India", Lahore: Sepik Stem Prince.

Russell, B. (2000). Marriage and Characters, London, Oxford press.

Sciolono, E. (2003). Shirac Wants Religious Attire Banned in Public Schools, France. 
Shaheed, F. (1986). The Cultural Articulation of Patriarchy: Legal Systems, Islam and Women, South Asia Bulletin, vol.6:1, pp.38-44.

Sheikh, A. M. (1987). Islam and New Thinking, Karachi, Islamic Book Corporation, pp.85-127.

Singh, Kishan (2005). The Liberated Woman, Azad Aurat in Punjabi. Lahore: Suchaiyat Kitab Ghar.

Singh, Prahald (2004). Purdah: the Seclusion of Body and Mind. Abstracts of Sikh Studies, vol.5:1.

Soharwardi, A. H. M. (2001). Rehabber Kama, Lahore, Muslim Publishers.

US Library of Congress. (n.d). Veiling and the Seclusion of Women. Washington: US Library of Congress.

Ziauddin, H. S. (2004). Woman Before and After Islam, Karachi, Aynor Health and Education Trust, p. 45.

Dr. Nasreen Aslam Shah is Meritorious Professor \& Chairperson in the Department of Social Work and Director, Centre of Excellence for Women's Studies, University of Karachi. 